\title{
A Study of the Classroom Research Skills Application for Educational Students
}

\author{
C. Waree
}

\begin{abstract}
The objectives of this research are: to develop and discover efficiency of the Classroom Research Skills Application for Educational Students to meet with criteria at $80 / 80$ and to study satisfaction level of students by using the Classroom Research Skills Application for Educational Students. The target group herein was 125 students who studied in Academic year of 2014 and interested in online registration. Target group was determined by using purposive sampling. Tools used in this research were 40 items of post-test contained in application on tablet, student's satisfaction evaluation form towards application usage. Data analysis was conducted to find efficiency of application as defined by criteria at $80.77 / 81.82$ and student's satisfaction level towards application usage of 125 students. The obtained mean was 4.35 and standard deviation was 0.68 . The results showed that the efficiency of the Classroom Research Skills Application for Educational Students was at 80.77/ 81.82 that was higher than defined criteria at $80 / 80$. In addition, Overall satisfaction of students towards application usage was in the highest level with the mean of 4.35 and standard deviation at 0.68. The obtained results were able to be used as guidelines for further development of learning activities management of other courses.
\end{abstract}

Index Terms-Application on tablet, a classroom research skills, learning, higher education.

\section{INTRODUCTION}

The current world is full of digital technologies therefore speed is currently preferred topic. In the recent decade, computer's processors have better competency by double times in every two years. It is expected that $5 \mathrm{G}$ mobile phones will have higher speed than that of current $4 \mathrm{G}$ mobile phones by 100 times and by 20,000 times compared to that of $3 \mathrm{G}$ mobile phones. The data from International Telecommunication Union showed that the proportion of the world populations who have used internet during the last 5 years increased from $34 \%$ to be $48 \%$. Do these technological changes transform life of teenagers too rapidly? Currently, students are able to connect with internet increasingly and there is a question whether this change is removing digital divide of new generation.

Among OECD member countries, there has been no digital divide on internet accessibility since 2012 and this data indicated that both writers with disadvantageous and advantageous economic status reported on their internet usage similarly because internet usage was considered as normal habit for this country group. However, when gathering all countries in the project, there was some interesting

Manuscript received October 12, 2018; revised May 12, 2019.

Chaiwat Waree is with the Faculty of Education of Suan Sunandha Rajabhat University, Thailand (e-mail: chaiwat.wa@ssru.ac.th). information that, in 2015, the student group with disadvantageous status seemed to use internet in higher level than that of students with advantageous status around 2 hours/week, especially in Belgium and Taipei. Students with disadvantageous status reported that they had used internet in higher level since 2012. OECD's mean revealed that students with disadvantageous status used internet in higher level on normal class days but there was no difference on the use of internet on weekends for both groups. In some countries with high level of digital divide (including Chile, Costa Rica, Latvia, Mexico, and Uruguay, students with advantageous status reported that they used internet in high level than that of students with disadvantageous status, for example, in Mexico, difference on internet usage between these two group of students were almost 20 hours/week with high level of digital divide on online activities enriching knowledge, for example, reading news on internet.

However, higher level of internet usage of students may not be good news because higher level of internet usage has no relationship with student's learning capabilities. The data indicated that internet usage may not give good effect as expected because it was found that students who reported that they frequently used internet had the score of science subject lower than that of students who used internet in moderate level in all school systems. Averagely, among OECD member countries, students had lower score of science subject by 2 points per increase of internet usage of 1 hour/week. The data also indicated that frequent use of internet outside schools gave negative effect to score of science subject when students used internet outside schools on normal class days. However, students who reported that they used internet on weekends higher than that on weekdays slightly had higher score of science subject. The reasons may be that it did not disturb their study time.

Averagely, it was found among OECD member countries that students with the age of 15 years who used internet in moderate level, i.e., 30 minutes, on class days or outside schools for 1-4 hours on class days and 2-4 hours on weekends had higher score of science subject than that of students who had never used internet or who were obsessed with internet usage (over consecutive 6 hours). Being obsessed with internet usage gave some mental effects reducing satisfaction towards life therefore students with this behavior were often late with low expectation towards their education. According to the report of OECD (2017), this may be the important reason causing students from Korea and Japan to spend their times with internet quite much compared to students from other countries, especially on class days

Many students throughout the world are highly interested and spend more time on internet inside and outside schools 
whereas students with disadvantageous social and economic status used internet increasingly in exponentiation. Although this matter was considered as positive thing in the previous decade, it was confusing in current world because the data indicated that internet usage caused students to have lower score when they used internet on class days. Moreover, student who used internet in high level also reported that their life happiness was lower although there were many innovations on the use of digital technology in studying before turning to be technology that is generally used. He results of this research had no intention to ask any person to stop using digital technology but it was asking all persons to use internet moderately with appropriate planning. In addition, this research also aims to prepare teachers to be ready to use this technology.

Such as, the researcher was interested in electronic media and utilizing innovation to convey an application on tablet to promote a classroom research skills for SSRU' students.

\section{OBJECTIVES}

To create the Classroom Research Skills Application for Educational Students to gain efficiency at 80/80 and achieve better level of student's satisfaction.

\section{HYPOTHESIS}

The Classroom Research Skills Application for Educational Students had efficiency level at 80/80 according to standard criteria and student's satisfaction level towards application on tablet to promote a classroom research skills was in high level.

\section{SCOPE OF RESEARCH}

Populations used in this research were students of SSRU in all years.

Target group used in this research on the Classroom Research Skills Application for Educational Students in all years obtained by using purposive volunteer sampling.

\section{DEFINITIONS}

1) The Classroom Research Skills Application for Educational Students means a web-based lesson promoting a classroom research skills in the online of students and anyone interested. Its contents are ordered in ordered from easy ones to difficult ones plus with practice and its answers in order to enable the students to know their results immediately. The students will be able to learn by themselves upon their personal capabilities.

2) Efficiency of application means abilities of the web-based lesson in building the learning achievement of the sample students from Faculty of Education, SSRU in order to enable them to obtain learning according to determined criteria of $80 / 80$.

The former 80 means efficiency of processes evaluated from the student's scores obtained from doing practices of each lesson during the class that is averagely $80 \%$.
The latter 80 means efficiency of the result evaluated from the scores of students for their post-test that is averagely $80 \%$ ".

3) The researchers also studied development of research skills of the students during the semester. Classroom research skills were consisted of: 1). Research problem determination; 2). Determination of problem solving or hypothesis; 3). Investigation and data collection; 4). Data analysis and synthesis; 5). Conclusion and research report.

4) Satisfaction of students means the feeling of students toward learning by using the Classroom Research Skills Application for Educational Students. This satisfaction was measured by using 10 items of Satisfaction Questionnaire upon the likert's 5 rating scales.

\section{RELATED RESEARCH DOCUMENT}

Jaruwan Siangpairoh [1] had studied for develop the scientific procedure skill and academic accomplishment about the natural polymer by organizing the science project-based instruction for 40 students of grade 12 by organizing 5 sets of project activities and the result shown that the accomplishment and integrated science skills of the student had risen statistical significantly at level of 0.05 , compared between before and after organizing the activity. Moreover, it was found that the students had high level of satisfaction for the science project-based instruction organizing.

Patcharee Janpeng [2] had improved the knowledge and research skill of the student in faculty of education, Khon Kaen University, by organizing the science project-based instruction in educational statistic and research subject to a sample group then collecting data by using research skill evaluation, research knowledge test, group work evaluation, behavior observation, interview, feedback result, self-evaluation, and also using 4 types of RBL to operate 4 research circuits. The result shown that the research skill improvement result by considering from overall research skill had the mean value at $75 \%$ of the max score. While considering in each side, it was found that the 2 skills that had highest score are the research problem defining skill and research operation process preparation, followed by the research operation skill. While considering in research knowledge, it was found that the mean value was $70 \%$ of the max score and the score had risen statistical significantly compared between before and after the studying.

Nattapong Chalardyam [3] had develop the science project activity for encouraging creativity of the 3rd interval students at the school in Sri Bun Rueang District, Nong Bua Lam Phu Education Service Area Office 1, by recruiting students from 25 schools then selected for 30 students. The result shown that the activity appropriateness evaluation score of the project activity was 4.40 which meant it was very appropriate and the result of mean value comparison between before and after study creativity score was found that the score of the sample group student had risen statistical significantly at level of 0.05 , compared between before and after studying.

The research about online lesson development about basic 
data structure has an objective to develop the online lesson, study the lesson effectiveness, comparing the academic accomplishment, and evaluate the satisfaction of the student towards the lesson. The sample group is 22 students of the 1 st year student of Information Technology field, faculty of Science and Technology, Muban Chombueng Rajabhat University which is acquired from Purposive sampling. The studying tools consist of online lesson, academic accomplishment test, lesson quality evaluation, and student's satisfaction evaluation. The statistics that used in data analysis are mean, standard deviation, and t-test Statistic. The result shows that the developed online lesson which is evaluated by the experts is found that the quality is in very good level at the mean value of 4.71 and the lesson effectiveness is at $81.82 / 87.43$ which is higher than the defined criteria. When analyzing and comparing the academic accomplishment of the studying group, it is found that the sample group had academic accomplishment risen statistical significantly at level of 0.01 , compared between before and after studying and the satisfaction of the students towards the lesson is in very high level at the mean value of 4.37 [4].

The research about online lesson development about computer system and architecture by dividing users into 3 groups as follows, system administrator, instructor, and student. The lesson is evaluated by the experts and the result is in good level. The result of online lesson effectiveness inquiring from the sample group of 20 students has the effectiveness value at $83.33 / 85.00$ which is higher than the setting criteria at 80/80 which mean that the developed online lesson has an effectiveness to apply in actual class [5].

The research about studying the interactive online lesson development about pre-printing technology. The result shows that the interactive online lesson has the content quality evaluation value at 4.25 which is in good quality level. The media production and presentation evaluation result is 3.95 which is in good quality level. The students have academic accomplishment risen statistical significantly at level of 0.01 , compared between before and after studying and the satisfaction of the students towards the lesson is in very high level at the value of 4.30 [6].

The research about a developing an Android application for Thai proverbs. The results of the study revealed that: 1). the application was on Android. Thai Proverb For students in Prathomsuksa 1. 2). Applications on Android. Thai Proverbs for Prathomsuksa 1 students are of high quality. 3). The students are satisfied with the level of satisfaction [7].

The research about Thai music players on tablets, the Android operating system. The purpose is to develop Thai music player on tablets Android operating system. This program was developed to help play Thai music is comfortable and easy for those who use. The user can play music at any time with the tablet operating system Android. The program consists of 3 types of instruments are alto bamboo xylophone, alto xylophone, and Khong wong. The user can play with the rhythmic sound. There are Thai musical notes that users can listen to sample songs and the history of each instrument. The system is developed in the manner of an application program. The program was evaluated by using Java based on the satisfaction of the program. Data were collected from two groups of experts, namely, three experts from the evaluation form, the mean of 4.39 and the standard deviation of 0.54 and the user's score of 30 . The average was 4.33 and the standard deviation was 0.66 very satisfied [8].

Chen et al. had studied the effects of tablet use in the learning process. By this research. Comparing the use of tablets with visual aids such as the blackboard projector and presentation media. This is a traditional teaching environment. The use of tablets for teaching and learning to facilitate the students in three aspects: 1). demonstrating the process of solving problems. 2). the use of audiovisual equipment. 3). the use of content. The original but changed presentation device. The result is that. The tablet can accommodate teaching styles and facilitate the students well [9].

\section{RESEARCH FRAMEWORK AND CONCEPT}

Research framework and concept is shown in Fig. 1.

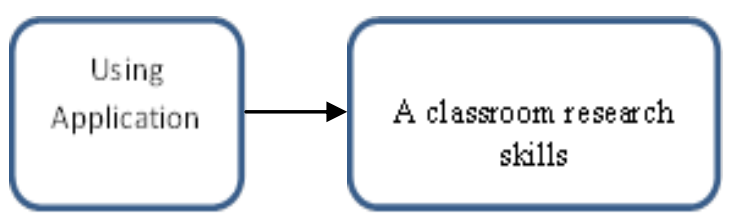

Fig. 1. Research framework and concept.

\section{RESEARCH PROCESS}

1) Studied papers and researches in order to synthesize a classroom research skills. Subsequently, the obtained results were classified, arranged systematically and created in the form of application.

2) The principle of application by ADDIE model contains Analysis, Design, Development, Implementation and Evaluation. Java is used to write applications installed on the Android operating system. PHP language used in the web server to upload files and chat.

3) Submit developed the Classroom Research Skills Application for Educational Students to experts for inspection and improvement.

4) Tried out improved the Classroom Research Skills Application with students who were not target group for further improvement and public relations.

5) Students who were target group studied created the Classroom Research Skills Application and took pre and post test. Subsequently, satisfaction of students was evaluated after their usage of application.

a) Tested students with test review of 3 online lessons. The obtained scores were collected as scores of formative evaluation.

b) 40 items of achievement test on online lessons were tested with students and the obtained scores were collected as scores of post-test.

c) 10 items of satisfaction evaluation form towards online lessons were commented by students.

6) The results were checked and the obtained scores of pre and post test were analyzed by using statistics in order to find efficiency at 80/80.

7) Student's satisfaction after using the Classroom Research Skills Application for Educational Students was analyzed and concluded. 


\section{CONCLUSION}

1) From development and try out of the Classroom Research Skills Application, it was found that it was suitable and efficient according to defined criteria calculated to be $80.77 / 81.82$ when utilizing with 125 students who were target group that was consisted with defined hypothesis.

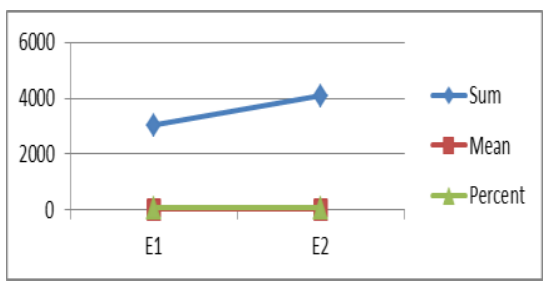

Fig. 2. Efficiency of application on tablet.

Fig. 2 shows efficiency of the Classroom Research Skills Application, it was found that efficiency of process (E1) provided in tests (mean score of 24.23) was calculated to be $80.77 \%$ and efficiency of results ( E2 ) (mean score of 32.73) was calculated to be $81.82 \%$.

2) From try out of the Classroom Research Skills Application, it was found that efficiency of process (E1) provided in tests was calculated to be $80.77 \%$ and efficiency of results (E2) was calculated to be $81.82 \%$. These application to promote a classroom research skills had higher efficiency than $80 / 80$ as defined therefore it could be concluded that these application had high efficiency as defined by criteria and they were able to be used for classroom instruction efficiently.

TABLE I: MEAN, STANDARD DEVIATION, AND SATISFACTION LEVEL OF STUDENTS TOWARDS THE CLASSROOM RESEARCH SKILLS APPLICATION FOR EDUCATIONAL STUDENTS

\begin{tabular}{|c|c|c|c|c|}
\hline Item & Assessment List & mean & S.D. & $\begin{array}{l}\text { Satisfaction } \\
\text { Level }\end{array}$ \\
\hline 1 & $\begin{array}{l}\text { Explanation of the classroom } \\
\text { research skills was clear and } \\
\text { understandable. }\end{array}$ & 4.38 & 0.65 & High \\
\hline 2 & $\begin{array}{l}\text { Students understand contents } \\
\text { of the courses. }\end{array}$ & 4.33 & 0.67 & High \\
\hline 3 & $\begin{array}{l}\text { Procedures of the classroom } \\
\text { research skills were clear and } \\
\text { appropriate. }\end{array}$ & 4.78 & 0.56 & Highest \\
\hline 4 & $\begin{array}{l}\text { Application starter was } \\
\text { appropriate. }\end{array}$ & 4.67 & 0.64 & Highest \\
\hline 5 & $\begin{array}{l}\text { Activities were appropriate } \\
\text { and interesting. }\end{array}$ & 4.6 & 0.8 & High \\
\hline 6 & Conclusion was appropriate. & 4.73 & 0.56 & Highest \\
\hline 7 & $\begin{array}{l}\text { Students were the center with } \\
\text { participation. }\end{array}$ & 4.4 & 0.7 & High \\
\hline 8 & $\begin{array}{l}\text { Students were able to ask } \\
\text { what questions with teachers. }\end{array}$ & 4.27 & 0.69 & High \\
\hline 9 & $\begin{array}{l}\text { Tests and practices were } \\
\text { appropriate. }\end{array}$ & 4.55 & 0.71 & High \\
\hline 10 & $\begin{array}{l}\text { Students required the } \\
\text { classroom research skills } \\
\text { obtained from application in } \\
\text { other subjects. }\end{array}$ & 4.84 & 0.42 & Highest \\
\hline \multicolumn{2}{|c|}{ Overall Assessment } & 4.56 & 0.64 & High \\
\hline
\end{tabular}

3) From the results of student's satisfaction towards learning with the Classroom Research Skills Application for Educational Students, it was found that overall student's satisfaction towards instruction using application on tablet was in the highest level, i.e., students had overall satisfaction towards application in high level with mean of 4.35 and item 10 was gained the highest satisfaction level of students. Average demand of students on creating application for other subjects was 4.84. For other evaluations, most of them had high level of satisfaction.

From Table I, it was found that students who studied through application had high level of satisfaction with the mean of 4.56 and Standard Deviation of 0.64. Students required the classroom research skills obtained from application in other subjects. and they also had the highest level of satisfaction with the mean of 4.84 and Standard Deviation of 0.42 . When considering on each item, it was found that most students had satisfaction in high level.

\section{DISCUSSION}

Efficiency of these application was in high level as expected at $80.77 / 81.82$ due to creation and development of such application. The researcher studied on basic data and analyzed work, contents, students who were target group, and behavioral objectives prior planning on creation and development to meet those behavioral objectives under explanation and suggestions of content expert for inspecting accuracy of contents, language correctness, appropriateness of design, instructional methods, and presentation. Subsequently, the obtained lessons were improved, developed, and tried out with a small student group in order to find further faults for additional improvement and development prior performing field tryout with 40 students. The results showed that efficiency of application was $80.77 /$ 81.82 that was satisfying and met with expected hypothesis. Student's satisfaction towards the Classroom Research Skills Application for Educational Students was in high level for all items because the research studied on psychology of learning of students before planning creation of application. Subsequently, the obtained results were planned for creation and development of complete application that was consistent with work of Chaiwat Waree who studied on Application Development on Tablet to Promote a Classroom Research Skills for SSRU'Students. The results showed that Efficiency of these application on tablet was in high level as expected at $80.77 / 81.82$ due to creation and development of such application on tablet and student's satisfaction towards application on tablet to promote a classroom research skills was in high level for all items [10].

\section{SugGestions}

\section{A. General Suggestions}

1) Students should be explained and suggested intermittently in order to understand subject contents correctly without explicit guidance. Students should be creative and take action by themselves.

2) There should be some period of time provided to students for training practical learning continuously and the 
duration of lecture should be reduced in order to enable students to repeat their practices contributing classroom research skills.

\section{B. Suggestions for Further Studies}

1) Application on tablet should be further applied to other subjects.

2) There should be some researches on the duration of classroom research skills of former students.

\section{ACKNOWLEDGMENT}

This research was supported by SSRU and Higher Education Research Promotion (HERP) in Office of the Higher Education Commission. Special thanks you to all experts and students of SSRU who helped and supported this project.

\section{REFERENCES}

[1] J Siangpairoh et al., "Development of science process skills and learning achievement using a science-based learning series natural polymers," in Proc. National Conference on Burapha University Chonburi, Burapha University, 2011, p. 15.

[2] P. Janpeng, "Research-based learning activities to improve knowledge and research skills of students," Khonkaen University Research Journal, vol. 1, no, 2, 2011, pp. 21-24.

[3] N Chalardyam, "The development of science projects to promote creativity of students in the third level of schools in Sriboonrung District Nong Bua Lam Phu Educational Service Area Office," Master's Degree in Education, Khon Kaen University, 2004.

[4] W Chaiyasit, Development of Online Tutorial on Structured Data Chom Bueng Rajabhat University, Ratchaburi, 2010.
[5] T Nilwan, Development of Online Lessons on Computer and Architecture. Bangkok, King Mongkut's Institute of Technology North Bangkok, 2003

[6] W Ploysri, Creating a Pre-printed Interactive Learning Technology, Bangkok: King Mongkut's University of Technology Thonburi, 2008.

[7] N Nonsrirach. (October 2014). Information about the operating system Android. [Online]. Available: http://potinimi.blogspot.com/2013/02/1_16.html

[8] K. Chootrakultham, "The development program. Play music on Android tablet, Android operating system," Master of Science Thesis, Information Technology Faculty of Information Technology, King Mongkut's University of Technology North Bangkok, 2012.

[9] F. Chen, J. Sager, G. Corbitt, and S. Kent, The Effects of Using a Tablet PC on Teaching and Learning Processes, June 2014.

[10] C. Waree, "Application development on tablet to promote a Classroom research skills for SSRU' students," Challenges and Solutions in Smart Learning, 2018, pp. 21-24.

Copyright $\odot 2019$ by the authors. This is an open access article distributed under the Creative Commons Attribution License which permits unrestricted use, distribution, and reproduction in any medium, provided the original work is properly cited ( $\underline{\mathrm{CC} \mathrm{BY} \mathrm{4.0}})$.

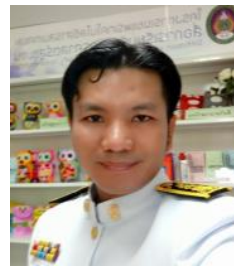

Chaiwat Waree was born in Nongchang, Thailand. $\mathrm{He}$ received the B.Ed. degree in Thai from the Srinakharinwirot University, TH, in 1999, the M.Ed degree in guidance and counseling psychology from the Srinakharinwirot University, TH, in 2002, the D.Ed. degree in curriculum and instruction from the Burapha University, TH in 2010and the LL.B. degree in laws from Thammasat University, TH, in 2017.

His research interests cover the pedagogy and psychology and education technology and environment science.

Asst. Prof. Dr. Chaiwat is a lecturer at Faculty of Education, Suan Sunandha University and External assessor for Office of National Education Standards and Quality Assessment, TH. 